\title{
ANALISIS PERBANDINGAN MODEL SPRINGATE DAN ALTMAN Z SCORE TERHADAP POTENSI FINANCIAL DISTRESS (STUDI KASUS PADA PERUSAHAAN SEKTOR KOSMETIK YANG TERDAFTAR DI BURSA EFEK INDONESIA)
}

\author{
Anggi Meiliawati \\ IKIP PGRI Madiun \\ anggimei93@gmail.com \\ Isharijadi \\ IKIP PGRI Madiun
}

\begin{abstract}
ABSTRAK
Penelitian ini bertujuan untuk mengetahui ada atau tidak perbedaan hasil prediksi potensi financial distress antara model Springate dan model Altman Z Score serta untuk mengetahui model dengan tingkat akurasi tertinggi dalam memprediksi potensi financial distress perusahaan sektor kosmetik yang terdaftar di Bursa Efek Indonesia. Jenis penelitian yang digunakan didalam penelitian ini adalah analisis kuantitatif. Populasi yang digunakan adalah seluruh perusahaan sektor kosmetik yang terdaftar di Bursa Efek Indonesia. Teknik pengambilan sampel dengan teknik purposive sampling. Teknik analisis yang digunakan dalam penelitian ini adalah analisis paired sampel t-test.

Hasil penelitian ini menunjukan bahwa model Springate dan Altman Z Score terdapat perbedaan signifikan dalam memprediksi potensi financial distress pada perusahaan sektor kosmetik yang terdaftar di Bursa Efek Indonesia, hal ini dikarenakan penggunaan rasio yang berbeda dalam perhitungan tingkat kesulitan keuangan. Hasil berikutnya menunjukan bahwa model Springate merupakan model terakurat dalam memprediksi potensi financial distress perusahaan sektor kosmetik yang terdaftar di Bursa Efek Indonesia dengan presentase akurasi sebesar 91,66\%, dimana tingkat akurasi model Altman hanya sebesar 60,41\%, hal ini dikarenakan dalam model Springate menggunakan rasio Earning Before Taxes to Current Liabilities (EBTCL), dimana rasio ini dinilai lebih dominan dalam mencerminkan kondisi perusahaan sektor kosmetik yang terdaftar di Bursa Efek Indonesia.
\end{abstract}

Kata Kunci : Model Springate, Model Altman Z Score, Financial Distress

\section{PENDAHULUAN}

Permintaan pasar yang tinggi menyebabkan persaingan dalam sektor kosmetik juga semakin tinggi. Devi dan Merkusiwati (2014 : 49) berpendapat bahwa jumlah pasar yang besar menyebabkan pasar kosmetik Indonesia tidak hanya diminati oleh indusri kosmetik lokal, tetapi juga diminati oleh industri impor. Mulai tahun 2012 pasar impor sudah mampu mencapai penjualan sebesar Rp.2,44 triliun dan angka tersebut masih terus meningkat sampai tahun ini. Dimana pada tahun 2013 nilainya naik 30\% menjadi 3,17 triliun. Angka tersebut terus naik sampai tahun ini karena mengingat pangsa pasar untuk produk kosmetik di Indonesia yang tinggi. Pasar kosmetik impor masih dua kali lipat lebih tinggi dari pasar lokal.

Menurut Darsono (2008 : 101) semakin terglobalisasinya perekonomian menyebabkan persaingan antar perusahaan menjadi semakin ketat, tidak hanya dalam suatu negara tetapi juga dengan perusahan di negara lain. Persaingan yang semakin ketat ini menuntut perusahaan untuk selalu memperkuat fundamental manajeman sehingga akan mampu bersaing dengan 
perusahaan lain. Ketidakmampuan mengantisipasi perkembangan global dengan memperkuat fundamental manajeman akan mengakibatkan pengecilkan volume usaha yang pada akhirnya mengakibatkan kebangkrutan perusahaan.

Situasi krisis dan persaingan yang tinggi seperti yang terjadi pada sektor kosmetik mempunyai pengaruh yang sangat besar karena operasi perusahaan yang tidak efisien akan sangat mempengaruhi kinerja perusahaan. Hal tersebut menyebabkan perusahaan berpotensi berada pada kondisi kesulitan keuangan dan kebangkrutan, maka dari itu sebagai langkah antisipasi diperlukan yaitu analisis yang lebih dini mengenai potensi financial distress.

Beberapa model prediksi untuk menilai potensi financial distress telah banyak dikembangkan oleh beberapa ahli setelah penelitian yang dilakukan oleh Beaver diantaranya ada model Altman Z Score dan model Springate. Dalam model yang dikembangkan oleh Altman, menggunakan 5 rasio keuangan dalam memprediksi potensi financial distress. Sedangkan Model Springate menggunakan 4 rasio keuangan.

Perbedaan penggunaan rasio keuangan antara model Springate dan Altman terdapat kemungkinan akan menyebabkan perbedaan hasil prediksi. Dari perbedaan hasil prediksi kedua model yang belum diketahui model mana yang paling akurat dalam memprediksi kesulitan keuangan perusahaan yaitu dalam kaitannya dengan perusahan sektor kosmetik. Selain kemungkinan terdapat perbedaan hasil prediksi, kedua model financial distress ini menpunyai tingkat akurasi yang berbeda. Menurut penelitian yang dilakukan oleh Altman(1968) tingkat akurasi untuk model AltmanZ Score ada dikisaran 95\% sementara itu untuk metode springate memiliki tingkat akurasi $92,5 \%$ hal ini didasarkan pada test yang dilakukan oleh Springate (1978).

Berdasarkan uraian latar belakang diatas, dapat dirumuskan permasalahan penelitian sebagai berikut :

1. Apakah terdapat perbedaan hasil prediksi potensi financial distress antara model Springate dan model Altman Z Score ?

2. Model prediksi manakah yang paling akurat dalam memprediksi financial distress perusahaan sektor kosmetik yang terdaftar dalam Bursa Efek Indonesia?

\section{KAJIAN PUSTAKA}

\section{Financial Distress}

Plat dan Plat (2006 : 169) memberikan definisi mengenai kesulitan keuangan atau Financial distress yakni, " The definition of financial distress is less precise than the legal actions that the define proccedings such as bankruptcy or liquidation". Sedangkan menurut Fahmi (2013 : 158) Financial distress dimulai dari ketidakmampuan perusahaan memenuhi kewajiban- kewajibannya, terutama kewajiban yangbersifat jangka pendek termasuk likuiditas, dan juga termasuk kewajiban dalam kategori solvabilitas.

Kesulitan keuangan suatu perusahaan disebabkan oleh beberapa kemungkinan. Darsono (2008:101-102) menjelaskan bahwa secara garis besar penyebab kebangkrutan bisa dibagi menjadi dua yaitu faktor internal dan faktor eksternal. Faktor internal adalah factor yang berasal dari bagian internal manajeman perusahaan. Sedangkan faktor eksternal bisa berasal dari faktor luar yang berhubungan langsung dengan operasi perusahaan atau faktor perekonomian secara makro. Ketidakmampuan untuk membaca sinyal - sinyal dalam kesulitan usaha akan mengakibatkan kerugian dalam investasi yang telah dilakukan. 
Menurut Fachrudin (2008:8) menyatakan bahwa kesulitan keuangan dapat ditinjau dari komposisi neraca - jumlah asset dan kewajiban, dari laporan laba rugi - jika perusahaan terus menerus rugi, dan dari laporan arus kas - jika arus kasmasuk lebih kecil dari arus kas keluar.

Financial distress dihitung menggunakan suatu formula atau model yang disebut sebagai model kesulitan keuangan. Menurut Subramanyam (2010 : 288), model kesulitan keuangan, yang umumnya disebut model prediksi kebangkrutan (bankruptcy prediction model), memberikan tren dan perilaku beberapa rasio tertentu. Karakteristik rasio tersebut digunakan untuk mengidentifikasi kemungkin kesulitan keuangan masa depan.

\section{Model Springate}

Gordon L.V Springate telah melakukan penelitian berkaitan dengan model prediksi potensi financial distress suatu perusahaan. Menurut Guinan (2009 : 236) (dalam Savitri Dita, 2016 : 4) metode Springate merupakan model yang dikembangkan oleh Springate (1978) dengan menggunakan analisis multidiskriminan Pada awalnya Springate menggunakan 19 rasio, namun setelah melakukan pengujian Springate mengambil empat rasio.

Menurut (Devi dan Merkusiawati, 2014 : 52). Keempat rasio tersebut dikombinasikan dalam suatu persamaan yang dirumuskan springate yang selanjutnya terkenal dengan istilah Model Springate. Berikut merupakan formula yang digunakan untuk menghitung nilai $\mathrm{Z}$ pada model Springate:

$$
\mathrm{Z}=1,3 \mathrm{~A}+3,07 \mathrm{~B}+0,66 \mathrm{C}+\mathbf{0 , 4 D}
$$

(Devi dan Merkusiawati, 2014 : 52)

Keterangan :

A = Working Capital to total Assets

$\mathrm{B}=$ Earnings Before Interest And Taxes to Total Assets

$\mathrm{C}=$ Earning Before Taxes to Current Liabilities

$\mathrm{D}=$ Total Sales to Total Assets

\section{Model Altman Z Score}

Pada tahun 1968 Edward I. Altman menemukan suatu formula atau model untuk memprediksi potensi kesulitan keuangan dimasa yang akan datang dengan yang disebut sebagai model Z Score. Menurut Sartono (2010 : 115) Z Score adalah skor yang ditentukan dari hitungan standart dikalikan rasio - rasio keuangan yang akan menunjukan tingkat kemungkinan kebangkrutan perusahaan. Altman Z-score menggunakan teknik statistik (analisis diskriminan berganda - multiple discriminant analysis) untuk menghasilkan alat prediksi yang merupakan fungsi linier dari beberapa variable penjelas (Subramanyam, 2010 : 288). Hasil penelitian yang dilaksanakan oleh Altman (1968) berkaitan dengan prediksi financial distress menghasilkan suatu fungsi diskriminan. The Final discriminant function is as follows (Altman, 1968 : 594):

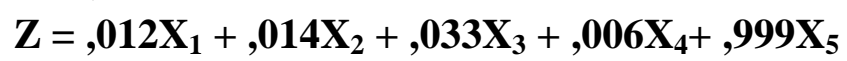

\begin{tabular}{|c|c|c|}
\hline \multirow[t]{6}{*}{ Dimana } & $\mathrm{X} 1$ & $=$ Working Capital/Total Asset \\
\hline & $\mathrm{X} 2$ & $=$ Retained Earnings $/$ Total Asset \\
\hline & $\mathrm{X} 3$ & $=$ Earnings before interest and taxes/Total Asset \\
\hline & $\mathrm{X} 4$ & $=$ Market Value equity/Book Value of total debt \\
\hline & $\mathrm{X} 5$ & $=$ Sales $/$ total asset \\
\hline & $\mathrm{Z}$ & $=$ Overall Indeks \\
\hline
\end{tabular}




\section{Hasil Penelitian Terdahulu}

Ni Made Evi Dwi Prihanthini dan Maria M.Ratna Sari (2013) melakukan penelitian dengan judul "Prediksi kebangkrutan dengan model Grover, Altman Z-Score, Springate dan Zwijewski pada perusahaan Food and Beverage di Bursa Efek Indonesia" memperoleh hasil bahwa antara model yang dibandingkan terdapat perbedaan yang signifikan dalam memprediksi kebangkrutan dengann tingkat akurasi tertinggi yang diraih model Grover kemudia disusul oleh model Springate, model Zwijewski dan terakhir model Altman Z-Score.

Halkadri Fitra (2015) dalam studi empirisnya denga judul "Analisis komparasi model potensi kebangkrutan pada perusahaan semen yang terdaftar di Bursa Efek Indonesia" memperoleh hasil bahaw terdapat perbedaan signifikan antara model yang dibandingkan yakni model Springate dan Altman Z Score, dengan tingkat akurasi model prediksi Springate dan Altman Z Score mempunyai tingkat keefektifan sama yakni 77,78\%.

Penelitian selanjutnya dilakukan oleh Lili Syafitri dan Triniadi (2016) yang berjudul "Analisis komparatif dalam memprediksi kebangkrutan pada PT Indofood Sukses Makmur", dalam penelitian tersebut diperoleh hasil bahwa kedua model yang dikomparasikan yakni molde Altman dan Springate terdapat perbedaan dalam memprediksi kebangkrutan dengan tingkat akurasi untuk model Altman Z Score adalah 0\% sedangkan model model springate $80 \%$.

Elvinna Wiwit Firma Meita (2016) juga telah melakukan penelitian dengan judul "Analisis Penggunaan Metode Altman, Springate, Dan Zmijewski Dalam Memprediksi Kebangkrutan Perusahaan Pertambangan Batubara Periode 2012-2014". Hasil dari penelitian ini adalah bahwa memang terdapat signifikan dalam memprediski kebangkrutan atau kesulitan keuangan antara model yang dibandingkan, hasil selanjutnya menunjukan bahwa model Springate yang memberikan tingkat persentase prediksi paling tinggi dibandingkan Altman modifikasi, Zmijewski dan Grover.

\section{Hipotesis Penelitian}

Berdasarkan hasil penelitian terdahulu maka hipotesis penelitian yang disusun adalah sebagai berikut ini :

H1 = Terdapat perbedaan signifikan antara model Springate dan Altman Z-Score dalam memprediksi tingkat potensi financial distress perusahaan sektor kosmetik yang terdaftar di Bursa Efek Indonesia (BEI).

$\mathrm{H} 2$ =Model Springate merupakan model prediksi potensi financial distress terakurat pada perusahaan sektor kosmetik yang terdaftar di Bursa Efek Indonesia (BEI).

\section{METODE PENELITIAN}

Jenis penelitian yang digunakan didalam penelitian ini adalah analisis kuantitatif. Objek penelitian yang digunakan adalah perusahaan yang terdaftar sebagai perusahaan sektor kosmetik di Bursa Efek Indonesia selama tiga tahun berturut - turut, yakni tahun 2012 - 2014.

Populasi dalam penelitian ini adalah seluruh perusahaan sektor kosmetik yang tercatat di Bursa Efek Indonesi (BEI) yang menerbitkan laporan keuangan auditan mulai tahun 2012 sampai dengan tahun 2014, dimana laporan keuangan yang digunakan adalah laporan per triwulan. Teknik pengambilan sampel menggunakan teknik purposive sampling, dimana teknik purposive sampling menurut Arikunto (2013:183) sampel bertujuan dilakukan dengan 
cara mengambil subjek bukan didasarkan atas strata, random atau daerah tetapi didasarkan atas adanya tujuan tertentu.

Adapun kriteria pengambilan sampel dalam penelitian ini adalah sebagai berikut :

1. Perusahaan sektor kosmetik yang tercatat pada BEI sampai tahun 2014

2. Perusahaan sektor kosmetik yang menerbitkan laporan keuangan per triwulan mulai tahun 2012 sampai dengan tahun 2014.

3. Semua perusahan sektor kosmetik di BEI mempunyai data yang lengkap yaitu data tersebut memuat seluruh komponen pengukuran variabel yang meliputi aktiva lancar, kewajiban lancar, total asset.

Berikut ini merupakan jumlah perusahaan yang dijadikan sampel berdasarkan teknik pengambilan sampel purposive sampling :

Tabel 1. Sampel Penelitian

\begin{tabular}{llc}
\hline No. & \multicolumn{1}{c}{ Keterangan } & Jumlah \\
\hline 1. & $\begin{array}{l}\text { Perusahaan Sektor Kosmetik yang terdaftar di Bursa Efek } \\
\text { Indonesia hingga tahun 2014 }\end{array}$ & 4 \\
\hline 2. & $\begin{array}{l}\text { perusahaan yang tidak menerbitkan laporan keuangan per } \\
\text { triwulan tahun 2012 -2014 }\end{array}$ & 0 \\
\hline 3. & $\begin{array}{l}\text { Perusahan dengan data tidak lengkap yaitu data yang tidak } \\
\text { memuat komponen pengukuran variabel. }\end{array}$ & 0 \\
\hline & \multicolumn{1}{c}{ Jumlah perusahan sampel } & $\mathbf{4}$ \\
\hline
\end{tabular}

Desain Penelitian digunakan dalam mencerminkan hubungan antara variable $\mathrm{X}$ dan Y. Desain penelitian digambarkan sebagai beikut ini :

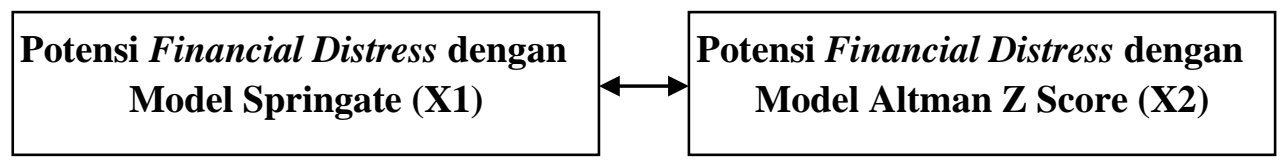

Teknik analisis data menggunakan uji t sampel berpasangan (paired sample t-test) dan perhitungan tingkat akurasi model. menurut Siregar (2012 : 248) Uji t sampel berpasangan ini digunakan untuk mengetahui ada tidaknya perbedaan nilai rata-rata antara dua kelompok data berpasangan. Sedangkan perhitungan tingkat akurasi digunakan untuk menghitung tingkat ketepatan model dengan memperhatikan type error dari setiap model. Menurut Hasanah (2010:44) Tingkat akurasi model dihitung dengan cara :

\section{Tingkat Akurasi = Jumlah prediksi benar/Jumlah Sampel x 100\%}

Sedangkan untuk type error dibagi menjadi 2 yakni type error I dan type error II, dimana masing - masing dihitung dengan cara sebagai berikut ini:

\section{Type I Error = Jumlah kesalahan Type I Jumlah Sampel x 100\% \\ Type II Error = Jumlah kesalahan Type II / Jumlah Sampel x 100\%}

(Hasanah, 2010: 44) 


\section{HASIL PENELITIAN DAN PEMBAHASAN}

\section{Hasil Pengujian Hipotesis Satu}

Pengujian hipotesis satu digunakan untuk menguji apakah antara model Springate dan model Altman Z Score terdapat perbedaan signifikan dalam memprediksi financial distress pada perusahaan sektor kosmetik yang terdaftar di Bursa Efek Indonesia. Uji hipotesisi satu menggunakan uji $\mathrm{t}$ sampel berpasangan atau paired sample t-test. Pengambilan keputusan yang menyatakan bahwa Ho diterima atau ditolak Menurut Siregar (2012 : 265) adalah sebagai berikut:

1. Jika: $-\mathrm{t}_{\text {hitung }}<\mathrm{t}_{\text {tabel }}<\mathrm{t}_{\text {hitung, }}$, maka Ho diterima.

2. Jika sig $>\alpha$ maka Ho diterima dan jika sig $<\alpha$ maka Ho ditolak.

Berikut ini merupakan hasil pengujian hipotesis satu menggunakan uji t sampel berpasangan atau paired sample $t-$ test:

Tabel 2. Hasil Pengujian Hipotesis 1 menggunakan paired sampel t-test

\begin{tabular}{|c|c|c|c|c|c|c|c|c|c|}
\hline & & \multicolumn{5}{|c|}{ Paired Differences } & \multirow[b]{3}{*}{$\mathrm{t}$} & \multirow[b]{3}{*}{ Df } & \multirow{3}{*}{$\begin{array}{l}\text { Sig. (2- } \\
\text { tailed) }\end{array}$} \\
\hline & & \multirow[b]{2}{*}{ Mean } & \multirow{2}{*}{$\begin{array}{c}\text { Std. } \\
\text { Deviation }\end{array}$} & \multirow{2}{*}{$\begin{array}{l}\text { Std. } \\
\text { Error } \\
\text { Mean }\end{array}$} & \multicolumn{2}{|c|}{$\begin{array}{c}95 \% \text { Confidence Interval } \\
\text { of the Difference }\end{array}$} & & & \\
\hline & & & & & Lower & Upper & & & \\
\hline $\begin{array}{l}\text { Pair } \\
1\end{array}$ & $\begin{array}{l}\text { MODELSPRINGATE - } \\
\text { MODELALTMAN }\end{array}$ & 1.44815 & 1.10341 & .15926 & 1.12775 & 1.76855 & 9.093 & 47 & .000 \\
\hline
\end{tabular}

Pengujian hipotesis satu $\left(\mathrm{H}_{1}\right)$ diperoleh bahwa nilai sig.(2-tailed) sebesar 0.000 , nilai ini lebih kecil dari $0.05(0.00<0.05)$ dengan hasil tersebut disimpulakan bahwa $\mathrm{H}_{1}$ diterima. Hasil ini menunjukan bahwa antara model Springate dan Altman Z Score terdapat perbedaan signifikan dalam memprediksi financial distress perusahaan sektor kosmetik yang terdaftar di Bursa Efek Indonesia.

\section{Hasil Pengujian Hipotesis dua}

Pengujian hipotesis dua digunakan untuk menguji tingkat akurasi model Springate dan Altman Z Score dalam memprediksi potensi financial distress perusahaan sektor kosmetik.

Tabel 3. Hasil Perhitungan Tingkat Akurasi Model

\begin{tabular}{|c|c|c|c|c|c|}
\hline \multicolumn{2}{|c|}{ REKAP } & \multicolumn{2}{|c|}{ Model Springate } & \multicolumn{2}{|c|}{ Model Altman } \\
\hline & & Distress & Nondistress & Distress & Nondistress \\
\hline \multirow[t]{2}{*}{ REAL } & Distress & $\mathbf{0}$ & $\mathbf{0}$ & $\mathbf{0}$ & $\mathbf{0}$ \\
\hline & Nondistress & 4 & 44 & 19 & 29 \\
\hline \multicolumn{2}{|c|}{ Type Error I } & \multicolumn{2}{|c|}{$8,34 \%$} & \multicolumn{2}{|c|}{$39,59 \%$} \\
\hline \multicolumn{2}{|c|}{ Type Error II } & \multicolumn{2}{|c|}{$\mathbf{0}$} & \multicolumn{2}{|c|}{$\mathbf{0}$} \\
\hline \multicolumn{2}{|c|}{ Tingkat Akurasi } & \multicolumn{2}{|c|}{$91,66 \%$} & \multicolumn{2}{|c|}{$60,41 \%$} \\
\hline
\end{tabular}

Pengujian atas hipotesis dua $(\mathrm{H} 2)$ diperoleh hasil bahwa tingkat akurasi model Springate sebesar 91,66\% lebih tinggi dari model Altman 60,41\% (91,66\%>60,41\%), dengan hasil tersebut dapat disimpulakan bahwa $\mathrm{H}_{2}$ diterima. Hasil ini menunjukan bahwa model springate merupakan model terakurat dalam memprediksi potensi financial distress perusahaan sektor kosmetik di Bursa Efek Indonesia. 


\section{Pembahasan}

Kedua model prediksi kesulitan keuangan setelah melalui pengujian yakni uji t sampel berpasangan terbukti memiliki perbedaan yang signifikan dalam memprediksi potensi financial distress perusahaan sektor kosmetik yang terdaftar di Bursa Efek Indonesia (BEI).

Perbedaan yang signifikan antara kedua model yakni model Springate dan model Altman dalam memprediksi potensi financial distress pada perusahaan sektor kosmetik adalah perbedaan rasio yang digunakan dalam perhitungan nilai $\mathrm{Z}$ masing - masing model. Model Springate menggunakan empat rasio keuangan dalam memprediksi potensi financial distress. Rasio yang digunakan dalam model Springate yakni rasio Working Capital to Total Assets (WCTA), Earnings Before Interest and Taxes to Total Assets (EBITTA), Earning Before Taxes to Current Liabilities(EBTCL) dan Total Sales to Total Assets (SATA). Sedangkan untuk Model Altman rasio yang digunakan sebanyak lima rasio keuangan yakni Working Capital to Total Assets (WCTA), Earnings Before Interest and Taxes to Total Assets (EBITTA), Retained Earning to Total Assets (RETA), Market Value of Equity to Book Value of Total Debt (MVEBVD) dan Total Sales to Total Assets (SATA).

perbedaan penggunaan rasio yakni rasio EBTCL, RETA dan MVEBVD yang digunakan kedua model dapat mempengaruhi perbedaan hasil prediksi potensi financial distress perusahaan sektor kosmetik. Rasio EBTCL digunakan dalam model Springate sementara rasio RET dan MVEBVD digunakan dalam model Altman Z Score. Perbedaan ini terlihat dari hasil prediksi, misalnya pada PT Mandom Tbk pada tahun 2013 triwulan I, model Springate menyatakan bahwa perusahaan berada pada kondisi non distress. Hasil sebaliknya ditunjukan oleh model Altman dimana ditahun dan triwulan yang sama yakni tahun 2013 triwulan II, perusahaan berada pada kondisi distress atau kesulitan keuangan.

Hasil pengujian atas hipotesis dua yang menunjukan hasil bahwa model Springate merupakan model yang paling akurt dalam memprediksi financial distress perusahaan sektor kosmetik yang terdaftar di Bursa Efek Indonesia (BEI).

Bagi manajeman model Springate lebih akurat dalam menghasilkan prediksi financial distress didasarkan pada rasio yang digunakan dalam perhitungan nilai $\mathrm{Z}$ pada model Springate. Dimana dalam model Altman tidak menggunakan rasio ini sebagai dasar perhitungan nilai Z. rasio yang dimaksud adalah rasio EBTCL (Earning Before Taxes to Current liabilities). Rasio EBTCL mengukur kemampuan perusahaan dalam menghasilkan laba dan laba tersebut digunakan untuk menutupi hutang jangka pendek. Rasio Earning Before Taxes to Current Liabilities (EBTCL), dimana rasio ini dinilai lebih mencerminkan kondisi perusahaan yakni melalui tingkat laba, biaya operasi dan pembayaran hutang, dimana pos tersebut sangat dominan dalam menentukan nilai Z. Seperti pendapat yang diungkapkan oleh Wulandari,dkk.(2013 : 11) rendahnya tingkat rasio laba sebelum pajak terhadap liabilitas lancar mengidentifikasikan adanya biaya operasi yang relative tinggi yang ditanggung perusahaan yang melebihi laba yang dihasilkan. Jika biaya operasi lebih tinggi dari laba yang dihasilkan maka kemungkinan perusahaan akan berada pada kondisi yang sulit terlebih lagi bagi perusahaan sektor kosmetik dengan persaingan pasar yang begitu ketat tidak dipungkiri jika perusahaan sektor kosmetik berpotensi bangkrut. Sehingga manajeman dapat mengambil keputusan yang tepat sehingga keputusan yang diambil tidak salah. 


\section{KESIMPULAN}

Berdasarakan tujuan penelitian dan pembahasan yang dijelaskan, maka dari penelitian ini dapat diambil kesimpulan sebagai berikut ini:

1. Antara model Springate dan model Altman Z Score terdapat perbedaan yang signifikan terhadap potensi financial distress perusahaan sektor kosmetik.

2. Dua model yang telah melakukan pengujian diperoleh hasil bahwa model Springate merupakan model terakurat dalam memprediksi potensi financial distress perusahaan sektor kosmetik yang terdaftar di Bursa Efek Indonesia.

\section{KETERATASAN PENELITIAN}

1. Objek penelitian hanya terbatas pada perusahaan sektor kosmetik yang terdaftar di Bursa Efek Indonesia.

2. Laporan keuangan yang digunakan sebatas laporan keuangan triwulan dan periode yang digunakan hanya 3 tahun.

3. Penelitian ini hanya bersifat membandingkan bukan menciptakan model prediksi financial distress yang baru.

\section{SARAN}

1. Bagi perusahaan dan stakeholder, prediksi lebih dini mengenai potensi perusahaan berada dikondisi kesulitan keuangan sangat diperlukan dikarenakan setiap perusahaan memiliki potensi berada pada kondisi financial distress

2. Objek yang digunakan dalam penelitian selanjutnya tidak hanya terbatas pada perusahaan sektor kosmetik yang terdaftar di Bursa Efek Indonesia melainkan perusahaan sektor yang lainnya.

3. Laporan keuangan yang digunakan bukan lagi laporan triwulan melainkan laporan keuangan tahunan dengan periode tidak hanya 3 tahun sehingga hasil penelitian lebih akurat.

4. Penelitian selanjutnya diharapkan dapat menciptakan model prediksi potensi financial distress yang baru sehingga penelitian dapat dikembangkan,

\section{DAFTAR PUSTAKA}

Altman, E.I. (1968). Financial Ratios, Discriminant Analysis and The Prediction of Corporate Bankruptcy. The Jurnal of Finance,vol.XXIII,No.4, Sept.https://perpus.go.id//. Diunduh pada 3 Maret 2016.

Arikunto, S. 2013. Prosedur Penelitian: Suatu Pendekatan Praktik. Jakarta: Rineka Cipta.

Baridwan, Z. 2010. Intermediate Accountig Edisi Kedelapan. Yogyakarta: BPFE.

Brigham, E., dan Houston, J. 2010.Dasar - Dasar Manajeman Keuangan,Edisi 11 Buku 1. Jakarta: Salemba Empat.

Darsono. 2008. Pedoman Praktis Memahami Laporan Keuangan. Yogyakarta: Penerbit ANDI. 
Devi, K., dan Merkusiwati. 2014 .Analisis Komparasi Potensi Kebangkrutan dengan Metode Z-Score Altman, Springate, dan Zwijewski Pada Industri Kosmetik Yang Terdaftar di Bursa Efek Indonesia. E-Jurnal Akuntansi Universitas Udayana 7.1(2014):48-63. https://propragandajurnal.com//. Diunduh pada 23 Maret 2016.

Fachrudin, Khaira,M. 2008. Kesulitan Keuangan Perusahaan dan Personal. Medan: USU Press.

Fahmi, I. 2013. Analisis Laporan Keuangan. Bandung: Alfabeta.

Fitra, H. 2015. Analisis Komparasi Model Prediksi Kebangkrutan pada Perusahaan Semen Yang Terdaftar di Bursa Efek Indonesia. SNEMA-2015. Padang. https://sekolahjurnal.co.id//. Diunduh pada 12 Maret 2016.

Hasanah, Nur. 2010. Analisis Rasio Keuangan Model Altman dan Model Springate sebagai Early Warning Sistem terhadap prediksi Kondisi Bermasalah pada bank Go Public. Jakarta : Fakultas Ekonomi dan Ilmu Sosial, Universitas Islam Negeri Syarif Hidayatullah. https://Jurkomuin.co.id.//. Diunduh pada 2 Maret 2016.

Ilhamdi, Taufik. 2016. Analisis Perbandingan Model Prediksi Kebangkrutan Menggunakan Model Altman Modifikasi, Springate, Zmijewski Dan Grover ( Studi Empiris Pada Perusahaan Sub Sektor Perkebunan Yang Terdaftar Di Bei ).Diploma thesis, UPT. Perpustakaan Unand. https://jurnalakuntansiupt.co.id.//. Diunduh pada 2 Maret 2016.

Kamal, Mustafa, I.2012.Analisis Prediksi Kebangkrutan pada Perusahaan Perbankan Go Public di Bursa Efek Indonesia. Skripsi. Makasar: Jurusan Manajeman Fakultas Ekonomi dan Bisnis Universitas Hasanuddin. https://kumpulanskripsilengkapco.id.//. Diunduh pada 6 Maret 2016.

Kasmir. 2010. Pengantar Manajeman Keuangan. Jakarta: Kencana.

Meita, Elvinna, M.F. 2016. Analisis Penggunaan Metode Altman, Springate, Dan Zmijewski Dalam Memprediksi Kebangkrutan Perusahaan Pertambangan Batubara Periode 2012-2014.Surabaya :Jurusan S1 Akuntansi, Fakultas Ekonomi, Universitas Negeri Surabaya.

Munawir, S. 2010. Analisa LaporanKeuangan. Yogyakarta: Liberty.

Plat, H., dan Plat, M., 2006.Understanding Differences Between Financial Distress and Bankruptcy. Review of Applied Economics, Vol. 2, No. 2,(2006): 141-157. https://financialeconomic.co.id//. Diunduh pada 6 Maret 2016.

Prihathini N., dan Ratna Sari. 2013. Prediksi kebangkrutan dengan model Grover, Altman ZScore, Springate dan Zwijewski pada perusahaan Food and Beverage di Bursa Efek Indonesia. E Jurnal Akuntansi Universitas Udayana.ISSN 23028556.https://perpustakanjurnal.com//. Diunduh 6 Maret 2016.

Rismawaty. 2012. Analisis Perbandingan Model Prediksi Financial Distress Altman, Springate, Ohslon, dan Zwijewski. Makasar: JurusanAkuntansi Fakultas Ekonomi 
Universitas Hasanuddin.https://kumpulanskripsilengkap.co.id//. Diunduh pada 6 Maret 2016.

Riyanto, B. 2010.Dasar- Dasar Pembelanjaan Perusahaan. Yogyakarta: BPFE.

Santosa, S, dan Ida. 2011. Analisis Kebangkrutan dengan Model Springate.Media Bisnis. Universitas Kristen Maranatha. https://jurnalakuntansiupt.co.id.//. Diunduh pada 2 Mei 2016.

Sartono, A. 2010.Manajeman Keuangan Teori dan Aplikasi Edisi 4. Yogyakarta: BPFE.

Sarwono, J. 2009. Statistik Itu Mudah : Panduan Lengkap Untuk Belajar Komputasi Statistik Menggunakan SPSS 16. Yogyakarta : Penerbit ANDI.

Sarwono, J., dan Suhayati, E. 2014. Riset Akuntansi Menggunakan SPSS. Bandung: Graha Ilmu.

Savitri, Dita, W. 2012. Analisis Prediktor Kebangkrutan Terbaik dengan Menggunakan Metode Altman, Springate, dan Zwijewski Pada Perusahaan Delisting dari Bursa Efek Indonesia Tahun 2012 (Studi Laporan Keuangan Tahun 2007-2011). Universitas Telkom.https://jurkomakuntasidanumum.co.id///. Diunduh pada 1 Maret 2016.

Siregar, Syofian. 2014. Statistik Parametrik Untuk Penelitian Kuantitatif : Dilengkapi Dengan Perhitungan Manual Dan Aplikasi SPSS Versi17. Jakarta : PT Bumi Aksara.

Sudana, M. 2011. Manajeman Keuangan Perusahaan Teori dan Praktik. Surabaya: Penerbit Erlangga.

Subramanyam, K.R., dan Wild, John J. 2012. Analisis Laporan Keuangan: Financial Statement Analysis Buku 1. Jakarta: Salemba Empat.

.2010. Analisis Laporan Keuangan: Financial Statement Analysis Buku 2. Jakarta: Salemba Empat.

Syafitri, L., dan Triniadi. 2016. Analisis Komparasi dalam Memprediksi Kebangkrutan pada PT. Indofood Sukses Makmur. Palembang: Jurusan Manajeman Keuangan STIE MDP.

Wulandari, V., dkk. (2014). Analisis Perbandingan Model Altman, Springate, Ohslon, Fulmer, CA-Score dan Zwijewski dalam Memprediksi Financial Distress. JOM FEKON Vol.1, No.2 Oktober.https://mediabaca.co.id//. Diunduh pada 4 Maret 2016.

http://m.wikipedia.com//

http://www.idx.co.id 